\title{
E-Government in Russia: Plans, Reality, and Future Outlook
}

\author{
Daria Gritsenko and Mikhail Zherebtsov
}

\subsection{INTRODUCTION}

Digitalization is a "Faustian bargain" for the state (Owen 2015, 15). On the one hand, it lends a promise to raise the efficiency of public administration by increasing the speed of bureaucratic processes and decreasing their cost. On the other hand, it poses a challenge to preserving the power, authority and control, threatening the public system to be "disrupted" by the new actors who previously had a limited opportunity to participate in public policy. For the government, exploring new forms of governance that relies on new Information and Communication Technologies (ICT) is arguably a way to navigate this bargain. As a result, in late-1990s, a new concept-electronic government or simply e-Government-became prominent on the agenda of government reformers (Heeks, R., and S. Bailur. 2007).

According to Layne and Lee (2001, 123), e-Government is "government's use of technology, particularly web-based Internet applications to enhance the access to and delivery of government information and service to citizens, business partners, employees, other agencies, and government entities." E-government borrowed heavily from applications and managerial approaches that originated in the private sector (Systems, Applications, and Products

D. Gritsenko $(\bowtie)$

University of Helsinki, Helsinki, Finland

e-mail: daria.gritsenko@helsinki.fi

M. Zherebtsov

Carleton University, Ottawa, ON, Canada

e-mail: mikhail.zherebtsov@carleton.ca 
[SAP], enterprise resource planning, portfolio analysis, and the like). This reliance on private-sector, market-based techniques provoked conversations that e-Government is a digitally enhanced version of the "new public management" (NPM), an ideology and number of more and less successful reforms that were implemented across the world in pursuit of greater government efficiency, the reduction of cost of public administration and improvement of public services by making the public sector more businesslike (Homburg 2004). Other scholars considered "digital era governance" as a reaction ("course-correction") to the new public management through the re-integration of processes and functions disintegrated in the course of NPM reforms (Dunleavy et al. 2006). ICT is, in short, an option for the government to remain in control while lowering the cost of bureaucratic government.

This chapter traces the development of e-Government in Russia from 2002 to 2020 through the lens of public administration reform. Whereas in many countries digitization of the public sphere was implemented on an already developed and properly functional government apparatus, in Russia both reform projects coexisted for quite some time. The public administration reform (2003-2013), led by the Ministry for Economic Development (then the Ministry of Economic Development and Trade), at its early stages was primarily focused on developing a new vertically integrated government infrastructure, reducing the burden of administrative redtape and over-regulation as well as streamlining the bureaucratic modus operandi. At the early stages, it was more intertwined with the civil service reform, controlled by the Presidential Administration, than with the initiatives in the sphere of Information and Communication Technologies (ICTs) that were championed by the Ministry for Communication (then Ministry for Communication and Mass Media). The overlap between the two major reforms created internal tensions that affected e-Government development trajectory. As a result, in the context of digitization and global e-Government development, the Russian case appears to be a peculiar instance.

Since its inception, the dynamics in e-Government development in Russia has been fluctuating (Zherebtsov 2019, 603). Only in 2012 the outcomes of activities pursued by the government became detectable, with Russia improving its United Nations (UN) e-Government ranking to place 27, having started at 58th place in 2003, and improving its eParticipation index for the same period from 0.05 to 0.65 (https://publicadministration.un.org/egovkb). After 2012, the development stagnated again. By 2016, the progress of e-Government included user-facing advancements (such as implementation of the Multi-Function Centers and a Unified Portal for public services (www. gosuslugi.ru), as well as introducing common services online such as identification, authentication, and payments systems) and "back office" solutions (setting up infrastructure to link different government institutions and establishing national databases) (Petrov et al. 2016, 5). Yet, the citizen uptake of many electronic services remained slow, some legislative changes were missing, and a significant part of the "back office" remained analogue (Petrov et al. 2016). 
Despite the ambitious plans and strategies, the implementation of e-Government in Russia still lags behind most of the European countries. We argue that the level of implementation fell short of projected goals because of the resistance of the incumbent public administration system, but also due to the discrepancy of e-Government ideas and ideals between the members of the governing elite.

The chapter proceeds as follows. First, we introduce general considerations on the digital transformation of government. Next, we discuss the stages of e-Government unfolding in Russia, paying attention to both progress and problems. We mainly discuss the federal reforms, allocating only brief remarks to the regional and local dimension of the process. The conclusion provides an assessment of the past e-Government reforms and an outlook for the near future.

\subsection{Digitalization and Government-Why and How?}

\subsubsection{Motivations for e-Government Uptake}

Garson (2006) put forward four theories to analyze the uptake of digital technology by the governments. First, technological determinism postulates that technology is a way (or even the way) of achieving change. It sees technology as an unstoppable force to which everyone, including governments, has to adapt. Second, the reinforcement theory suggests that technology tends to reinforce the existing power structure. ICT has no "magic powers," but it is a tool of control and domination that governments can deploy to maintain their authoritative position. Third, the systems theory assumes that while technology does not prescribe change, it is the main force that enables change. ICTs can be used to integrate organizations, to achieve higher levels of efficiency, to improve performance, and this motivates governments to deploy them. Finally, the sociotechnical theory suggests that human factors determine the outcomes of technological change. ICT can be developed to support centralization or decentralization, democracy or autocracy, hierarchy or networks, depending on the design choices made by whoever develops and implements the system. Following the recent advances in sociotechnical change theorizing, we suggest that any technology is not implemented in a vacuum but rather embedded in a sociopolitical context and that individual practices and perceptions are indicative of the contextual sociotechnical change. Thus, the uptake and functioning of digital technology in public administration will depend on the (political) context upon which this technology is superimposed.

In the context of non-democratic political regimes, a further theory of government digitalization has been proposed. Maerz (2016), bridging the reinforcement and the sociotechnical theories, has argued that e-Government is used by competitive authoritarian regimes, such as Russia or Kazakhstan, as a tool for gaining internal legitimacy. She suggested that e-Government allows to "simulate" transparency and participation, offering the citizens a number of services and engagement opportunities which, nevertheless, remain a façade covering the authoritarian core. The study concluded that e-Government 
facilities shall not be viewed as a sign of democratization, but rather a tool of legitimation that helps preserving authoritarianism. Examining the Chinese example, Ma et al. (2005) argued that e-Government can simultaneously strengthen administrative control and promote economic development without empowering individual citizens in a democratic sense. In addition, concerns have been raised with regard to privacy and data protection practices that accompany digitalization of non-democratic states (Seifert and Chung 2009). Greitens (2013) suggested that "authoritarianism online" rests on three building blocks: control over the online content, citizen surveillance via online tracking, and the promotion of regime goals through various internet applications. E-Government features prominently in both surveillance and regime promotion, making it valuable in an authoritarian context (Stier 2015). Summing up, there is a potential complex of motivations to adopt e-Government, and those have been decoupled from the early "democratizing" perspectives.

\subsubsection{Stages of e-Government Development}

Layne and Lee (2001) put forward four stages of a growth model for e-Government: (1) cataloguing, (2) transaction, (3) vertical integration, and (4) horizontal integration. The first stage starts when a government opens simple websites that tell about the government, its structure, and functions. Next, the experimentation of public sector with digital tools proceeds to transactions, an interaction model where the user (citizen) interacts with the government via an electronic interface (service portal on a government website or mobile application) to receive public services ranging from a healthcare appointment to filing a tax declaration or registering a marriage. Government remains a service provider for citizens and businesses, but their interaction is "virtual" and online rather than in-person. The third stage is marked by deeper cooperation between various government departments. Different levels of government are also integrated, so that a citizen can contact one governmental body and complete any level of governmental transaction, often referred to as a "one-stop shopping"-public service provision.

The fourth stage of government digitalization is often connected to the idea of "government-as-a-platform" (GaaP). The concept of GaaP was coined by Tim O'Reilly (2011), a US (United States) based author, futurist, and entrepreneur, who envisioned significant benefits from shifting from "state as a provider" to "state as an enabler" of services. GaaP, which differs from previous $\mathrm{e}$-Government initiatives in that the core digital infrastructure is shared between public and private sectors, is not a "platform for government," but a platform for governance, where government is one of the participants, service producers, and innovators. A similar idea has been presented by Linders (2012) as "wegovernance" and by Janssen and Estevez (2013) as "lean government"-government provides a platform on which stakeholders deliberate, while the public authorities retain their "orchestrating" functions. Another related concept, government 2.0 (analogous to web 2.0), was proposed by Taewoo Nam (2012) 
who has been advocating for crowdsourcing, Application Programming Interfaces (APIs), and "citizen hacking" as means to improve the democratic quality and efficiency of government.

GaaP can be seen as a new package of ideas imported to public sector from business management. This time, the intellectual roots are in the "disruption theory" originating from the work of Christensen et al. (2015), which has become a mantra of Silicon Valley. Disruption stands for "a form of libertarianism deeply rooted in the technology sector, a sweeping ideology that goes well beyond the precept that technology can engage social problems to the belief that free market technology-entrepreneurialism should be left unhindered by the state" (Owen 2015, 7). The proponents of the concept emphasize its interactive character and the enabling potential (citizens as co-producers of public services) (O'Reilly 2011). Building new services from scratch means also that the old bureaucratic practices are not simply transferred into a digital form, but rather that procedures are renewed. The critics argue that the changing relationship between the state and society mediated by "big data," software code and algorithms is a form of technocratic "solutionism" that effectively undermines democratic governance (Williamson 2016).

\subsection{Russian Government's Digitalization Story}

\subsubsection{Towards an e-Government (2002-2009)}

In the early 2000s Russia's backwardness in the field of digital technologies was obvious to the new Russian leadership with the public sector demonstrating almost no signs of progress in this sphere. While global leaders were gradually transitioning to the new digitization agenda, Russia only had to conduct a fullfledged public sector reform. This prompted the reformers to launch both reforms simultaneously, yet independent from each other. Under the Federal Target Program (hereafter FTP), "Ėlektronnaâ Rossiâ (2002-2010)" (Electronic Russia) e-Government was first developed as a separate reform. In its initial stage, the concept embraced a large agenda of democracy promotion, a significant modernization of the general ICT infrastructure, including its public sector component. The approach seemed reasonable as both required substantial development before they could be merged. The "Electronic Russia" program included a full spectrum of measures, necessary to build the complex government Information Technologies (IT) infrastructure. Particularly, the measures included the development of the systems of identification and authentication as well as digital (paperless) workflow. In addition, the program prescribed the development of solutions to integrate various independently built state information systems to ensure a complex services delivery through the multifunctional centers. Yet in the first years of the program implementation the only visible result of the reform was the increased Internet presence of the federal government bodies through a network of interconnected departmental websites. The actual building of the e-Government infrastructure had not 
begun almost until the end of the program. Throughout its implementation the program was plagued by multiple drawbacks, including critical underfunding, lack of coordination, inefficient use of budget funds as well as a comparatively low prioritization and insufficient political attention to the reform. Since its launch, the "Electronic Russia (2002-2010)" Program was revised at least five times, substantially narrowing down its scope and ambitious plans due to both, a very ambitious and loosely coordinated agenda as well as inefficiency of reform management and misappropriation of funds (Rudycheva 2011, Polenova 2011).

Only by 2006, reformers managed to complete the development of key nodal elements of the government IT infrastructure of the government-State Automated (Information) Systems "Vybory" (Elections, http://www.cikrf. $\mathrm{ru} / \mathrm{gas} /$ ), "Pravosudie" (Justice, https://sudrf.ru/), "Zakonotvorčestvo" (Lawmaking, http://parlament.duma.gov.ru/), and "Upravlenie" (Administration, http://gasu.gov.ru/)—and proceed to designing elements of e-Government, particularly the Single Portal of State and Municipal Services (www.gosuslugi.ru), launched in 2010. These systems automate certain significant political and administrative processes. Although being independent from one another and focused on specific tasks, these systems constitute the information backbone of any electronic government and their successful launch and further utilization demonstrate a significant step forward in regard with digitization of the government sphere. The overall inefficiency of the program was acknowledged by both the country leadership and key experts. In order to increase the effectiveness of the Program, in 2008 the Ministry of Communications of Russia conducted a review of the implementation of the Program. According to the report, many of the objectives of the Program have not been achieved. In particular, interdepartmental electronic interaction was not actually realized. In addition, standardization of IT solutions was not widely used, leading to the situation when the created hardware and software systems were not used to their full potential due to the lack of systems interoperability.

In this regard, in 2009, the Program was restarted and complemented by the independent "Conception of e-Government development until 2010," emphasizing the strategic priority of e-Government. This was an important shift towards the recognition of the leading role of IT solutions in the future modernization of the national public sector. This restart coincided with the beginning of the presidency of Dmitry Medvedev that was marked by several modernization efforts. During 2008, a legal review had been conducted and new federal laws prepared. On February 9, 2009, the Federal Law 8-FZ " $\mathrm{Ob}$ obespečenii dostupa $k$ informacii o deâtel'nosti gosudarstpennyh organov $i$ organov mestnogo samoupravlenia" (On the access to information on the activity of the state and local authorities) has been issued, together with an Order of the Government of Russia №478 from June 15, 2009, “O edinoj sisteme informacionno-spravočnoj podderžki graždan i organizacij po voprosam vzaimodejstviâ $s$ organami ispolnitel'noj vlasti $i$ organami mestnogo 
samoupravleniâ $s$ ispol'zovaniem informacionnotelekommunikacionnoj seti Internet" (On the unified system of information and reference support of citizens and organizations on questions concerning their cooperation with the state and local authorities by means of the Internet), and the Presidential Decree N721 from September 9, 2009, has brought changes into the FTP "Electronic Russia 2002-2010" to enable a unified technical infrastructure for the Russian e-Government. The evaluation of the program's unsatisfactory outcomes coincided with the substantial revision of the results of the Public Administration Reform. By 2010 it was obvious that the outlined reform agenda was exhausted. Like the "Electronic Russia 2002-2010" Program, the public administration reform also failed to implement and consolidate new principles of public administration, based on the NPM approach. The initial strategy to build a triple-layer structure of functionally segregated government agencies and thus ensure organizational diversification of the Russian public sector did not come to fruition. It was planned to assign the policy creation and implementation function to ministries, the control and oversight function-to state services, and services provision function-to state agencies, which would be politically and administratively independent from each other. Instead, the reform resulted in the creation of a vertically integrated system of government with the dominant top-down vector of bureaucratic accountability. Further modernization in this direction had come to a logical standstill and required the revision of the strategy.

\subsubsection{Building e-Government (2011-2015)}

After six years, the Public Administration Reform had been demonstrating little evidence of improving the efficiency of the government and quality of public service. The reform failed to achieve most of the measurable targets that were laid in it. By the same token, the FTP "Electronic Russia 2002-2010" was openly regarded as a failure. In these circumstances, it has become evident that the approach to separately implement both modernization projects had proven its inefficiency. For the third phase of the Public administration reform it was decided to put the development of Information and Communication Technologies in the core of the government modernization project. Thus, Russia joined a plethora of countries in conversing its public administration into e-Government. To ensure that a bigger picture is not missed, the e-Government reform was harmonized with another overarching Federal Program, "Informacionnoe obshbstvo 2011-2020" (Information Society, Government Decree N 1815-r from October 20, 2010), which set as its key objective the digitization of all spheres of the Russian society.

The focus of the reform was made on conversing public services, internal workflow and data government into a digital format. In the minds of reformers, e-Government would further extend the single-window access principle of public services delivery at the customer end through the united single portal of state and municipal services. The portal was aimed to provide information on 
available services and government regulations, digital application forms, and payment services. To ensure access to multiple services from different federal, regional, and municipal government agencies, the portal should be integrated with the Unified Identification and Authentication System (Petrov et al. 2016, 26). Such ambitious goals determined a complete reformatting of the government IT back office.

The vector of further modernization was determined by the adoption in 2010 of the Federal Law No. 210-FZ "Ob organizacii predostavleniia gosudarstvennyh i municipal'nyh uslug" (On the organization of delivery of state and municipal services), which de-jure prohibited government agencies from requesting the previously collected and stored personal information of applicants. The clause made imperative interagency collaboration at least in the contest of services delivery. In junction with policies to enforce the promotion of digital workflow, the main focus of the back-end modernization shifted towards the SMÈV (Sistema mežvedomstvennogo èlektronnogo pzaimodejstviiâ, System for Electronic Interagency Collaboration). Initially, it was perceived as an IT solution connecting the EPGU (Edinyj portal gosudarstpennyh $i$ municipal'nyh uslug, Unified Portal of State and Municipal services) with similar regional portals and multi-function centers, on the one hand, with services providersauthorized government agencies, on the other. The functioning of the digital government infrastructure also prompted the development of the Unified System of Identification and Authentication in order to ensure proper user access. Finally, the approach included the synchronization of the system with the State Information Systems that were built in the previous period.

Thus, the next step in public administration reform was effectively converted into building e-Government in Russia. Yet despite such significant shift in the agenda, the overall approach seemed to remain intact. As with the earlier reform, it was decided to focus on the infrastructure development projects with the implicit expectation that they would foster policy and operational changes. In addition, the approach replicated the earlier and already proven faulty expectations that the infrastructural transformations will prompt the regions to catch up. The reformers assumed that regional government would take advantage of the developed infrastructure and utilize option of hosting its regional e-Government segments.

At the same time, reflecting on past experience, the decision was made to ensure a smooth transition to the predominantly online service delivery model. To ensure non-disruptive on-boarding, it was decided to enhance the functionalities of the already built territorial multifunction citizen service centers, which were tasked with promoting and facilitating citizen's use of the online portal. However, since the centers were under the jurisdiction of the Ministry of the Economic Development, this decision did not eliminate the dual administrative control over the reform, which had plagued the reform process before. Under the new system, the division of authority over the reform was made as follows: the Ministry for Communication was predominantly tasked with the development of e-Government infrastructure and the Ministry for Economic 
Development-with policy and oversight over the reform as well as the "offline" on-boarding. This decision not only influenced the efficiency of coordination but also had a negative impact on the political capital necessary for the reform.

In designing the reform, key focus was made on developing normative standards, prescribing the reform's end-points, and prioritizing infrastructure development over policy transformation. This allows defining the reformers' approach as genuinely technocratic. Reformers refused to account to the existing capacity of the bureaucracy to influence implementation of the reform not only by slowing down its complicated and/or unfavorable aspects but also by resisting to certain policy proposals that undermine its control over certain policy domains. Following Pournelle's famous Iron Law of Bureancracy (Pournelle 2006), stating that in any organization some people work to further the organization's goals, while others work for the organization itself, any evolutionary attempts to reduce the size of public administration or level of control over certain areas through any means of improvement and optimization, including digitization, would face with the administrative actions to curtail and diminish their effectiveness. Coupled with the lack of precise measurable indicators for the efficiency of the reform, the first reform was inadvertently set to demonstrate underperformance. Those implementation and performance indicators, proposed in the documents, did not justify the selected targets. For example, implementation has confirmed that the chosen reform methods would not lead to the conversion of 70 percent of all state and municipal services to the electronic format (Order of the Government No.2516-r, December $25,2013)$.

The implementation of the reform in 2011-2013 revealed the deficiencies of the initial reform sign, as it struggled to achieve the designated goals. Despite the positive dynamics and ever-growing number of registered online citizens and users, coupled with advanced and well-designed United Portal of State and Municipal Services, the overall impact of digitization did not meet expectations. Most popular and frequently used online services were purely informational (i.e. required further offline actions to proceed) and the majority of registered online users opted for the option of simplified registration that excluded enhanced user verification and authentication. Subsequently, this permitted only limited access and functionality that, particularly, excluded the processing of payments and other operations that required the substantive utilization of personal and financial data (for more details refer to Zherebtsov 2019).

From the operations perspective, the reformers failed to engage with regions, which in practice, resulted in the emergence of two parallel and often unsynchronized systems of e-Government portals - for the federal services, on the one hand, and for regional and municipal services, on the other. Speaking of the EPGU exclusively, less than fifteen percent of federal and less than ten percent of regional and municipal services were fully available electronically. The regular monitoring of regional e-Government development, conducted by the 
Ministry for Economic Development revealed substantial discrepancy of the quality and quantity of services, available on regional portals. The reform implied the monopoly of the state-owned corporation, Rostelecom on providing hosting and infrastructure for e-Government. It was expected that regions would "rent" the provided infrastructure; yet the degree of compliance with this policy initiatives appeared to be low. Rich regions (such as Moscow, St. Petersburg) have already invested in the development of their own portals, and poor regions found the Rostelecom hosting prices too restrictive to use the infrastructure and realized that building local solutions is cheaper. Coupled with technical difficulties that affected the implementation of electronic workflow (for example, Internet bandwidth restricted access to regional databases and registries) that impacted the interagency collaboration, the first phase of e-Government reform in Russia was regarded inefficient.

As a result, substantial changes were made to the design of the reform. After conducting the inventory of existing services and analyzing users' activities on the portal, the decision was made to focus on converting the most actively used services to a fully online format. The shift of focus from the extensive (quantity of services) to intensive (quality of services) development of the Portal was accompanied by the change from institution-oriented to user-oriented approach. Services, which were previously grouped by institutions, responsible for their delivery, started to be aggregated on the basis of user life situations, substantially improving the quality and user-friendliness of the portal.

Innovations, visible to the users, were supported by a considerable transformation of the government back-end functionality. In fact, the entire architecture of e-Government was reconsidered in order to put SMÈV-System for Electronic Interagency Collaboration - into the core of the infrastructure. In terms of the architecture design, the initial "hardware-based" approach, focused on the digitization and webification of the already existing infrastructure and processes, was replaced with the "solution based" principle that focused on supporting IT solutions fostering intra-governmental communication and data exchange. Reformers refocused on the creation of system of key IT gateways around key components of e-Government in an attempt to unite and synchronize previously developed objects of government IT-infrastructure.

The "bumpy" road to e-Government was noticed and reflected in Russia's standing in international e-Government ratings. The e-Government development index, prepared by the United Nations on a biannual basis, marked a significant progress between 2010 and 2012, when Russia moved from 59th to the 27th place. Yet, between 2012 and 2016, Russia failed to improve its performance, falling to the 35 th position with very limited positive dynamics in the index itself, allowing other countries to move forward. The situations started to improve in 2018, when the country moved to the 32nd place with substantial increase of its index score. This decade-long dynamic correlates with the ups and downs in Russia's e-Government development process.

The period between 2011 and 2016 was marked by moderate actual growth and propagation of e-Government services. According to the official statistics, 
the total number of registered users demonstrated exponential growth from just over 3 million in 2012 to 13 million in 2014, to 40 million in 2016 . However, a more critical analysis reveals a quite different situation. When these data are compared with official demographics from Rosstat in the period between 2012 and 2014, the number of users registered on the EPGU appears to be less than 12 percent of the total population, older than 18 years and less than 18 percent of active internet-users from the same age group. Moreover, at least one-third of all registered users opted for the simplified registration, thus not having full access to the portal. All this reduces the number of Portal users with full and unrestricted access to only 8.3 percent of Russian citizens and 12.5 percent of internet-users.

As demonstrated by Hilov (2014), the reported data on activity dynamics was based on the number of submitted, not executed requests. According to the author, only $87 \%$ of the requests for federal services were executed and the numbers for regional and municipal were much lower-36\% and 19\% respectively. Services delivery also differed substantially between the top ten regions averaging 167 requests per 1000 people compared with bottom ten having only 13.8 requested per 1000 people. In addition, the quantity of recipients of fully electronic services remained relatively low during the same period of time. Only about $3.2 \%$ of Russian citizens opted for this option in 2015 , while others still used the walk-in option (Dobrolyubova and Alexandrov 2016). In 2013, $63 \%$ of respondents did not interact with public authorities online because they "prefer a personal visit and personal contact" (Rosstat 2014).

In addition to the digitization of services, the e-Government reform proclaimed significant improvement of regulatory capacity of the public administration, positively affecting the business climate. It was expected that converting to the digital format would reduce the administrative and regulatory burden on business, thus enhancing the business climate and fostering economic growth. Yet existing evidence demonstrates that the business community remained disengaged with the government, despite all improvements in the IT-infrastructure. The 2015 annual report of the office of the business ombudsman to the President (Doklad 2015) stated that the government failed to impose any significant changes with respect to the existing regulatory burden. Despite the positive feedback on the EPGU, almost $52 \%$ of respondents outlined in 2015 that administrative burden has been increasing, accounting for 10 to 20 percent of the total company's revenue. The business community indicated that the reform failed to streamline regulatory activities of the state agencies, as some still enforce regulations, the implementation of which would inevitably result in fines and other penalties.

It required a substantial review of the initial reform project in order for e-Government to catch up and become the leading form of public administration in Russia. The reform resulted in the creation of advanced and modern IT infrastructure of digital government with the most notable transformations occurring in the public services delivery aspect and particularly in the context of constant modernization of the EPGU. In this regard, late start (in 
comparison with the leading countries) leveled the negative consequences of the technocratic approach. In reality, the very approach contributed to the rapid modernization of the IT infrastructure, as it did not account for how the developed infrastructure would be utilized by the bureaucratic apparatus. Nevertheless, the reform process revealed substantial flaws in the reform design and implementation, whose persistence at the following stages have the potential to become a very detrimental factor.

\subsubsection{Beyond the e-Government-Government as a Platform (2016-Now)}

The FTP “Èlektronnoe pravitel'stvo" (Electronic Government) was concluded in 2016. The citizens gradually accepted the new form of interaction with regulators and bureaucrats, in particular young and middle-aged people found it convenient, and ever-growing Internet coverage (mobile first) made wider adoption possible (Shipov 2016). As electronic public services started to become normalized all over Russia, the most recent iteration of public sector digitalization-Gosudarstvo kak platforma (government as a platform)-had been presented as a concept in April 2018. The concept has been under development since 2016 at CSR (Centr strategičeskih razrabotok, Center for Strategic Research), a think-tank curated by Alexei Kudrin, former Finance Minister and the current head of the Russian Audit Chamber, belonging to the political group of "reformers." The document outlines how O'Reilly's concept could be transplanted into the Russian public administration. While it is not an official governmental program or strategy, it is worth noting that the leading political party "Edinaâ Rossiâ" (United Russia) has included GaaP into the program for the November 9, 2018, united election day in a few regions. While the idea is very new, it has already gained traction among the regional politicians and will most probably continue its way into the federal policy-making.

As discussed in Sect. 3.2.2, "government as a platform" is going a step further in comparison to e-Government, suggesting innovation in service delivery by allowing third parties to re-think public services without the direct intervention of authorities. The model for this is to provide application programming interfaces (APIs) to citizens and businesses who can innovate on the formats of service production and delivery. Hence, GaaP is "shifting services into new digital formats that will allow governments to continually gather huge reservoirs of data on citizens' everyday activities, interactions and transactions - data that can then be mined, analyzed and used as insights to shape services-whilst simultaneously encouraging citizens to become responsible participants in the coproduction and provision of those digital services" (Williamson 2014). This set of ideas can be found in the CSR "Gosudarstvo kak platforma" concept paper (2018). The concept links to the Digital Economy of the Russian Federation program 2018-2024 that focuses on enhanced adoption of digital technologies in economic and social spheres (for more, see Lowry 2020). 
The justification of digital public administration is built around a number of explicit and implicit problem statements. First, it mentions lack of trust in state institutions. The lack of accountability and citizen control over public administration is regarded as a cause of inefficient bureaucracy. Corruption, mistakes, and heavy administrative burden are expected to be alleviated by GaaP. Second, lack of trustworthy data and ineffective, slow processes of data acquisition are considered to make the state slow to respond to various challenges. Authorities are presented as intermediaries between the citizens and their data who stall the efficiency and speed of public service delivery. The lack of horizontal, interdepartmental integration is seen as a further challenge. The resistance of the incumbent public administration system leads to "digital feudalism," meaning that each public body develops its own digital systems and processes that are not interoperable. The concept also criticizes the Multi-Function Centers and a Unified Service Portal, which were introduced as a part of the Electronic Government program, claiming that they were a tactical win that turned into a strategic loss, since they preserve the existing inefficient system and block further development and genuinely new ways of public administration.

The CSR document is interesting because it presents GaaP as a solution to a number of problems in the current system of public administration. The concept states that poor public service delivery is the reason for the lack of innovation in Russian economy, while lack of reliable data and data analytics tools leads to suboptimal decision-making. The basic assumption is that the global competitiveness of a state is a direct consequence of the way the public administration is run, hence, introduction of GaaP is a way of ensuring Russia's competitiveness in the global arena.

However, even more revealing is the analysis of implicit problems through the analysis of expected benefits. The two key characteristics of GaaP are being human-oriented (čelovekoorientirovannyj), yet human-independent (čelovekonezavisimyj). These are suggesting that the current system is not oriented towards the citizen but rather towards the state and its offices, while all the decisions are dependent on concrete public servants. The idea of automated, algorithmic, and big data-driven decision-making as fair, neutral, and citizen-oriented, emerges throughout the document. "Intellectual agents" (intellektual'nye agenty) - artificial intelligence (AI) driven decision-making algorithms - are expected to be at the core of public service. Bureaucratic process and personal responsibility in decision-making - both seen as problems of the current system-would therefore be substituted by an algorithmic process that eliminates personal contact. As a consequence, most of the public servants will be IT professionals and machine-learning specialists.

What is different in the CSR concept compared to the models developed by O'Reilly and other "visionaries" is the state-centric and hierarchical nature of developing and governing the transition to GaaP. Unfolding of the architecture, systems, and services is not simply curated by the state, but rather supervised. The state is the main developer and could involve third parties to develop additional services if it considers this necessary. There is only a marginal role for 
the citizens who are re-conceptualized as users benefiting from the new GaaP. Each citizen is expected to acquire a "digital twin" — a set of dataalready at birth and the amount of data constituting the digital representation of every person will grow with the time. The citizens therefore will be "datafied" (Hintz et al. 2018). Yet, no systems for citizen participation in GaaP development and maintenance are proposed. The concept lacks any instruments of accountability or citizen audit (for more on government data, see Chap. 22).

As a result, the problems outlined in the concept are not being addressed through deliberation or other forms of democratic participation, but automation and AI are taking the place of digital democracy. The word "democracy" (or its derivatives) does not emerge in the concept a single time. Focus on technology rather than democratic process is emblematic: the technocratic narrative of information technology as a source of increased efficiency for the state has been a prevailing ideology of the ruling elite since 2012 when Medvedev's techno-political modernization agenda was curtailed.

\subsection{Regional and Local Dimension of e-Government}

The federal government has been the main driver of e-Government reforms and the main changes have happened at the federal level. Yet, also at the regional and local level, there have been various digital initiatives. Kabanov and Sungurov $(2016,85)$ studied the uptake of e-Government in the Russian regions. They argue that "the diffusion of e-Government itself was to a large extent the result of a vertical influence of the federal government." This is well illustrated through examining different facets of e-Government. In case of public procurement, the new procurement law (94-FZ) introduced at the federal level mandated the creation of transparent and available information access. As a result, all regional governments created portals to implement the law, even though almost a half have only done so to fulfill the formal requirements (McHenry and Pryamonosov 2010). In the case of e-Government payments, there has been no unified legal provisions on their installment, hence, significant regional variation can be observed (McHenry and Borisov 2005). While today all the regional governments have Internet presence, the functionality of the websites differs considerably. Kabanov and Sungurov (2016) suggest that a more mature e-Government in a given region is a combination of several factors, including bureaucracy effectiveness, technological advancement, investment in ICT, and relatively democratic political regime. Techno-optimistic orientation of the regional governing elite, especially the governor, also seems to be important, at least judging from the cases of Sakha Republic (Yakutia, Ajsen Nikolaev), Moscow (Sergey Sobyanin), Belgorod oblast (Konstantin Poležaev), and so on.

Similar dynamics can be observed at the local level. While we have not observed relevant empirical studies in Russia, Johnson and Kolko (2010) compared the nation-level and the city-level e-Government initiatives in Central 
Asia, concluding that local-level initiatives are more citizen-oriented and transparent. This probably is related to the fact that at the local level, governments are not mandated to develop electronic services or participation tools. A useful illustration is provided by the analysis of civic technology platforms, meaning digital platforms for citizen participation and engagement with the government, conducted by one of the authors. Civic technology is usually realized as an online or mobile application that allows citizen participation in urban management, planning and design through consultations, opinion polling, ratings, requesting repair, complaints, participatory budgeting, and other similar engagement forms. For the government, civic technology can perform several functions, from creating a new communication channel to get instant input on the bureaucratic performance and respond to the daily needs of the citizens with improved services, to a scalable method for collecting and analyzing popular needs, preferences, ideas, and values. According to our estimation, about half of the Russian regional capital deployed civic technology platforms over the past five years (2014-2019).

\subsection{Concluding Remarks}

This chapter traced the development of e-Government in Russia from 2002 to 2020 through the lenses of public administration reform. During the first period-2002-2009-an FTP "Electronic Russia" was launched in parallel with a major administrative reform. While there has been an overlap between the two, both reforms failed to implement the principles of New Public Management (NPM) to an extent that would yield them success. The second period-2010-2015-can be identified within the scope of the next FTP "Information Society 2011-2020," and particularly, its key project "Electronic Government (2011-2015)." This project departed from an idea of e-Government as a complement or partial substitute to the "real" government and focused on the development of infrastructure for electronic public service delivery. Finally, the third period-2016-present-started the development of "government-as-a-platform" concept, that has so far not been implemented but raised much interest among various actors, as well as provoked debates regarding the future of data and digital infrastructures for its collection, processing, and storage.

These developments were aimed at serving several goals. The first aim was to improve the efficiency and decrease the cost of public administration, two central ideas of the NPM agenda. The projects cannot be regarded as pure "window-dressing," as much of what has been achieved, in particular in the area of electronic service delivery, has had a positive effect on citizen-state interactions. In simple terms, for an average citizen in a non-conflictual situation, it has become more convenient, quick, and simple to communicate with government authorities. The e-Government project also had a pronounced political economy aspect as one of its goals has been to secure the country's competitiveness internationally, appearing as a more attractive location to both 
live and do business. Yet, the intentions did not match the reality and businesses noticed an increased administrative burden as a result of the innovations. Eventually, while driven by "good intentions," the discrepancy between the plans and their implementation appeared large.

The review of the near two decades of digitalization of the public sector in Russia, performed through three consecutive federal programs/concepts, reveals an authentic style of conducting such reforms that can, at least partially, explain the observed discrepancy. First of all, there is a highly pronounced technocratism of planning and preparing the reform designs. Unlike in most democratic countries, e-Government reforms were designed with the state, rather than the citizen, at the center. Such unique style of the reforms can be regarded beneficial only for vast infrastructure-building projects, when it is important to enhance control over multifaceted implementation tasks in order to ensure a more or less balanced development of all components of the digital government infrastructure. Yet it seems that adhering to the same strategy at the following reform stages may result in multiple drawbacks and would require multiple corrections of the entire reform design.

Secondly, a significant level of centrality and directive management of the reforms is the characteristic of Russian e-Government implementation. The top-down approach was even embedded in the design of the reform. The ideas emanated from the federal center and were further adopted by the regions. There has been only limited opportunity for the subnational units to influence the progression of e-Government reforms. The initial inflexible approach did not propose cooptation strategies. Regions were given two options: to comply with the proposed solutions or to develop their own. This resulted in the emergence of two separate e-Government platforms-federal and regional. Moreover, the municipal level of self-government has been completely disregarded in the initial plans.

Finally, we identify the resistance of the incumbent public administration system (what is called "digital feudalism" in the CSR GaaP Strategy) and clash of ideas within the ruling elites with regard to the ways in which e-Government should be implemented and what is its ultimate purpose. The former is determined by the natural lack of the initiative of existing bureaucracy to adhere to the notion that digitization improved administration by reducing its size and streamlining key policies. The idea of seamless government, coupled with the reduced control over exclusive policy domains, does not sit well in the selfdetermination of current public administration leaders. The latter can be crudely reduced to the ideological disagreement between Medvedev, who started planning for the Electronic Government, and Putin, under whose government it has mainly be implemented.

The transition to the GaaP model has further exposed the flaws of the technocratic approach, as the emphasis is made on functional and policy changes and lesser on the transformation of infrastructure. The latter becomes necessarily distributed and uncontrollable from the single center. This undermines the entire top-down ideology of governance in Russia that critically modified the 
course of the 2003-2013 public administration reform and significantly impacted the e-Government implementation at each development stage. The prolonged inability to adapt to the new principle of distributed and delegated governance over policy domains with blurred administrative boundaries will destine the new reform to follow the footsteps of its precursors.

\section{REFERENCES}

Christensen, C.M., M.E. Raynor, and R. McDonald. 2015. What Is Disruptive Innovation. Harvard Business Review 93 (12): 44-53.

Dobrolyubova, E., and O. Alexandrov. 2016. E-government in Russia: Meeting Growing Demand in the Era of Budget Constraints. In International Conference on Digital Transformation and Global Society, 247-257. Cham: Springer.

Doklad Prezidentu RF-2015. 2015. Commissioner for the Protection of the Rights of Entrepreneurs in Russia. Accessed November 11, 2019. http://doklad.ombudsmanbiz.ru/doklad_2015.html.

Dunleavy, P., H. Margetts, S. Bastow, and J. Tinkler. 2006. New Public Management Is Dead-Long Live Digital-Era Governance. Journal of Public Administration Research and Theory 16 (3): 467-494.

Garson, G.D. 2006. Public Information Technology and e-Governance: Managing the Virtual State. Jones \& Bartlett Learning.

Greitens, S.C. 2013. Authoritarianism Online: What Can We Learn from Internet Data in Non-democracies? PS: Political Science \& Politics 46 (2): 262-270.

Heeks, R., and S. Bailur. 2007. Analyzing e-Government Research: Perspectives, Philosophies, Theories, Methods, and Practice. Government Information Quarterly 24 (2): 243-265.

Hilov, P. 2014. Kak ulučšit' itogi raboty portala gosuslug, ili Nehitrye manipulâcii s čislami [How to Improve the Results of the Public Services Portal, or Simple Manipulations with Numbers]. D-Russia, July 31. Accessed November 7, 2019. http://d-russia.ru/kak-uluchshit-itogi-raboty-portala-gosuslug-ili-nexitrye-manipulyacii-s-chislami.html.

Hintz, A., L. Dencik, and K. Wahl-Jorgensen. 2018. Digital Citizenship in a Datafied Society. John Wiley \& Sons.

Homburg, V. 2004. E-Government and NPM: A Perfect Marriage? In Proceedings of the 6th International Conference on Electronic Commerce, 547-555. ACM.

Janssen, M., and E. Estevez. 2013. Lean Government and Platform-Based GovernanceDoing More with Less. Government Information Quarterly 30: S1-S8.

Johnson, E., and B. Kolko. 2010. E-Government and Transparency in Authoritarian Regimes: Comparison of National-and City-Level e-Government Web Sites in Central Asia. Digital Icons: Studies in Russian, Eurasian and Central European New Media 3: 15-48.

Kabanov, Y., and A. Sungurov. 2016. E-Government Development Factors: Evidence from the Russian Regions. In International Conference on Digital Transformation and Global Society, 85-95. Cham: Springer.

Layne, K., and J. Lee. 2001. Developing Fully Functional e-Government: A Four Stage Model. Government Information Quarterly 18 (2): 122-136. 
Linders, D. 2012. From e-Government to We-Government: Defining a Typology for Citizen Coproduction in the Age of Social Media. Government Information Quarterly 29 (4): 446-454.

Lowry, A. (2020). "Russia's Digital Economy Program: An Effective Strategy for Digital Transformation?" In Gritsenko D. et al. (Eds): The Palgrave Handbook of Digital Russia Studies, Palgrave Macmillan.

Ma, L., J. Chung, and S. Thorson. 2005. E-Government in China: Bringing Economic Development Through Administrative Reform. Government Information Quarterly 22 (1): 20-37.

Maerz, S.F. 2016. The Electronic Face of Authoritarianism: E-Government as a Tool for Gaining Legitimacy in Competitive and Non-competitive Regimes. Government Information Quarterly 33 (4): 727-735.

McHenry, W., and A. Borisov. 2005. E-Government Public-Private Partnerships: The 'Gorod' Payments System in Siberia. Journal of Enterprise Information Management $18(5): 625-640$.

McHenry, W.K., and D. Pryamonosov. 2010. Emerging Electronic Procurement in Russia's Regional Governments. Journal of Public Procurement 10 (2): 211-246.

Nam, T. 2012. Suggesting Frameworks of Citizen-Sourcing Via Government 2.0. Government Information Quarterly 29 (1): 12-20.

O'Reilly, T. 2011. Government as a Platform. Innovations: Technology, Governance, Globalization 6 (1): 13-40.

Owen, T. 2015. Disruptive Power: The Crisis of the State in the Digital Age. Oxford Studies in Digital Politics.

Petrov, O., M. Bunchuk, A. Stott, and Y. Hohlov. 2016. Digital Government 2020: Prospects for Russia (English). Washington, DC: World Bank Group. http://documents.worldbank.org/curated/en/562371467117654718/Digital-government2020-prospects-for-Russia.

Polenova, I. 2011. Innovacii pod podozreniem [Innovations Under Suspicion]. Rossijskaâ gazeta-Federal'nyj pypusk, no. 196 (5572).

Pournelle, J.E. 2006. Pournelle's Iron Law of Bureaucracy [Online]. Accessed November 19, 2019. http://jerrypournelle.com/archives2/archives2mail/ mail408.html\#Iron.

Rosstat. 2014. "Pričiny otkaza ot ispol'zovaniyâ seti Internet pri polučenii gosudarstvennyh i munitsipalnyh uslug, po tipam poseleniâ i polu, po Rossijskoj Federatsii, Tablica 5.19". Accessed July 2, 2020. https://www.gks.ru/free_doc/new_site/ business/it/fed_nablcroc/PublishData\%5CReports\%5CReports_2014.html.

Rudycheva, N. 2011. 'Èlektronnaâ Rossiâ: čem zakončilos' i kto vinovat? ['Electronic Russia': How Did It End and Who Is to Blame?] cnews.ru. Accessed December 6, 2018. http://www.cnews.ru/reviews/free/gov2011/articles/article2.shtml.

Seifert, J.W., and J. Chung. 2009. Using e-Government to Reinforce GovernmentCitizen Relationships: Comparing Government Reform in the United States and China. Social Science Computer Review 27 (1): 3-23.

Shipov S. 2016. O kačestve perevoda gosudarstvennyh uslug v elektronnuû formu [On the Quality of the Transfer of Public Services in Electronic Form], December 12. Accessed November 22, 2019. http://old.economy.gov.ru/wps/wcm/connect/ economylib4/mer/resources/9ef8582f-fa8e-4f72-9476-d6ff5cea2e 02/2.pdf. 
Stier, S. 2015. Political Determinants of e-Government Performance Revisited: Comparing Democracies and Autocracies. Government Information Quarterly 32 (3): 270-278.

Williamson, B. 2014. Knowing Public Services: Cross-Sector Intermediaries and Algorithmic Governance in Public Sector Reform. Public Policy and Administration $29(4): 292-312$.

. 2016. Political Computational Thinking: Policy Networks, Digital Governance and 'Learning to Code'. Critical Policy Studies 10 (1): 39-58.

Zherebtsov, M. 2019. Taking Stock of Russian e-Government. Europe-Asia Studies 71: 1-29.

Open Access This chapter is licensed under the terms of the Creative Commons Attribution 4.0 International License (http://creativecommons.org/licenses/ by/4.0/), which permits use, sharing, adaptation, distribution and reproduction in any medium or format, as long as you give appropriate credit to the original author(s) and the source, provide a link to the Creative Commons licence and indicate if changes were made.

The images or other third party material in this chapter are included in the chapter's Creative Commons licence, unless indicated otherwise in a credit line to the material. If material is not included in the chapter's Creative Commons licence and your intended use is not permitted by statutory regulation or exceeds the permitted use, you will need to obtain permission directly from the copyright holder. 